\title{
RAZVOJ KNJIŽNIČNIH ZBIRKI \\ KAO PREDUVJET I MJERA RAZVOJA KNJIŽNICE
}

\author{
LIBRARY COLLECTION DEVELOPMENT \\ AS A MEASURE FOR LIBRARY DEVELOPMENT
}

\author{
Radovan Vrana \\ Odsjek za informacijske i komunikacijske znanosti \\ Filozofski fakultet, Sveučilište u Zagrebu \\ rvrana@ffzg.hr \\ Jasna Kovačević \\ Knjižnica i čitaonica Bogdana Ogrizovića \\ Knjižnice grada Zagreba \\ jasna.kovacevic@kgz.hr
}

UDK / UDC 027.3:021

Izvorni znanstveni rad / Original scientific paper

Prihvaćeno / Accepted: 18. 4. 2017.

\section{Sažetak}

Razvoj knjižničnih zbirki pripada najvažnijim aktivnostima u sklopu upravljanja svakom knjižnicom i toj je aktivnosti potrebno posvetiti posebnu pozornost jer o njoj ovisi uspjeh knjižnice u korisničkoj zajednici. Posebnu ulogu u razvoju knjižničnih zbirki imaju korisnici knjižnica koji izražavanjem svojih potreba i želja u istraživanjima korisnika ili u neposrednom kontaktu s knjižničnim osobljem aktivno sudjeluju u izgradnji knjižničnog fonda knjižnice i oblikovanju knjižničnih usluga. U ovom radu predstavljeni su rezultati istraživanja korisnika Knjižnice i čitaonice Bogdana Ogrizovića u Zagrebu (Knjižnice grada Zagreba) s ciljem prikupljanja podataka o njihovim pogledima i stavovima o knjižničnom fondu navedene knjižnice. Temeljno pitanje istraživanja bilo je jesu li korisnici knjižnice zadovoljni dostupnošću građe u knjižnici. Istraživanje je provedeno uz pomoć tiskanog anketnog upitnika na prigodnom uzorku korisnika knjižnice (članova i nečlanova) u razdoblju od 1. 7. 2016. do 24. 9. 2016. U istraživanju su

Vjesnik bibliotekara Hrvatske 60, 1(2017), 79-102

ISSN 0507-1925

(C) VBH 2017. 
mogli sudjelovati i članovi i nečlanovi knjižnice. Rezultati istraživanja pokazuju kako su razlozi dolaska u knjižnicu vlastito obrazovanje i istraživanje, a potom slijede zabava $\mathrm{i}$ hobi te druge aktivnosti, kao i da tom prigodom korisnici u prosjeku posuđuju po 2 knjige. Korisnici su izrazili želju da na raspolaganju imaju više knjiga, i to književnosti, znanstvenih informacija (u digitalnom formatu) te publicistike u odnosu na ostale vrste građe poput časopisa i novina. Korisnici su također ukazali na razloge čitanja knjiga i časopisa, a to su najčešće vlastito zadovoljstvo, obrazovanje, osobni razvoj i zabava. Korisnici su također mogli izraziti i stupanj zadovoljstva građom, odnosno njezinom dostupnošću, i u tom su pitanju iskazali visok stupanj zadovoljstva knjigama, časopisima i novinama, dok su tek nešto manje zadovoljstvo povezali s digitalnom građom, udžbenicima, priručnicima, enciklopedijama, leksikonima i rječnicima. Završni dio istraživanja odnosio se na stavove korisnika o knjižnici, pri čemu su najistaknutiji pozitivni stavovi vezani uz građu i potrebe korisnika, a nešto manje povoljni uz pronalaženje građe. Rezultati istraživanja bit će primijenjeni u razvoju fonda knjižnice u kojoj je provedeno istraživanje.

Ključne riječi: narodna knjižnica, izgradnja fonda, vrednovanje fonda, istraživanje korisnika

\section{Summary}

Development of library collections is one of the most important activities in management of every library and this activity requires special attention because it has a great impact on the success of libraries in user communities. Users have a special role in library collection development as they participate actively in library holdings development with their needs and wishes. Users express their needs and wishes by participating in user research studies and in direct contact with library staff. This article presents the results of a research study conducted in the "Bogdan Ogrizović" library in Zagreb (Zagreb City Libraries). The aim of the research was to collect data about users' views and opinions about library holdings, and the main question of the research was to find out whether library users are satisfied with the library holdings or not. The research was carried out by use of a printed questionnaire using convenience sampling of library users (members and non-members) in the period from 1 July 2016 to 24 September 2016. Both library members and non-members were eligible for participation in the research study. The most common reasons for visits to the library were individual's education and research, and the average number of books borrowed per visit was two. The research has shown that users want more books on their disposal, particularly fiction, scientific information (in digital format) and non-fiction, but have shown somewhat less interest in other library materials like journals and newspapers. The users also indicated their reasons for reading books and journals and these were pleasure, education, self-development, and fun. They demonstrated high degree of satisfaction with the available library materials, including books, journals, and newspapers. On the other hand, they indicated lower degree of satisfaction with digital materials, textbooks, handbooks, encyclopedi- 
as, lexicons, and dictionaries. The last part of the research focused on the users' opinions about the library. The results have shown positive opinions about library material and services and less positive about library material location and finding them on shelves. Generally, the results indicate the high degree of users' awareness of the need for new and various library materials. The results of the research will be integrated into future library collections development as intended.

Keywords: public library, collection development, library holding evaluation, user study

\section{Uvod}

Razvoj knjižničnih zbirki pripada najvažnijim aktivnostima u upravljanju knjižnicom. Tijekom provedbe te aktivnosti knjižničari moraju donositi složene odluke o nabavi građe na temelju vlastitih planova, ali i potreba i želja korisnika za određenim temama i vrstama građe. ${ }^{1}$ Uz potrebe, želje i interese korisnika, ta se aktivnost oslanja i na prioritete zapisane u temeljnim dokumentima knjižnica poput strateških planova i smjernica o nabavi građe te na prioritete korisničke zajednice u kojoj knjižnica djeluje. ${ }^{2}$ Razvoj knjižničnih zbirki u zadnjih nekoliko desetljeća mijenjao se pod utjecajem faktora poput informacijske i komunikacijske tehnologije, smanjenih proračuna knjižnica i novih načina upravljanja knjižničnim zbirkama u odnosu na ranija razdoblja razvoja i rada knjižnica. ${ }^{3} \mathrm{Ti}$, ali i drugi, faktori utječu na upravljanje knjižničnim zbirkama, pa su istraživanja korisnika knjižnica postala jednom od najpopularnijih metoda prikupljanja podataka za potrebe upravljanja knjižnicama. Kako bi bile utvrđene potrebe i želje korisnika za nabavom građe te zadovoljstvo postojećom građom u Knjižnici i čitaonici Bogdana Ogrizovića u Zagrebu, pokrenuto je istraživanje korisnika kojemu je svrha pomoći procesu planiranja razvoja knjižničnih zbirki na temelju podataka prikupljenih u ovom istraživanju, ali i u cjelokupnom razvoju knjižnice općenito, a posebno u upravljanju zbirkama.

\section{Razvoj knjižničnih zbirki}

Knjižnične zbirke srce su svake knjižnice i zbog toga se nalaze u žarištu napora knjižničara koji njima upravljaju. Aktivnost razvoja knjižničnih zbirki zamišljena je s ciljem uspostave kvalitetnih informacijskih izvora u knjiž-

\footnotetext{
Peet, Lisa. Format follows function. // Library Journal 140, 14(2015), 34.

2 Johnson, Peggy. Fundamentals of collection development and management. ALA, 2014. Str. 1.

3 Stoller, Michael. Building library collections: it's still about the user. // Collection Building 24, 1(2005), 5.
} 
nici ${ }^{4}$, tj. knjižničnih zbirki koje odgovaraju raznovrsnim potrebama korisnika knjižnice. Kako bi taj cilj bio postignut, svaki segment svake zbirke mora biti razvijan uz primjenu raspoloživih potencijala u knjižnici koji su u skladu s važnošću zbirke koju se razvija s ciljem ostvarenja misije knjižnice i zadovoljenja potreba njezinih korisnika. ${ }^{5} \mathrm{~S}$ obzirom na to da je razvoj zbirki dio procesa upravljanja knjižnicom, on je važan za ukupni razvoj knjižnice te je uključen u vrednovanje rada i razvoja knjižnice koji u obzir uzima fond, usluge i prostor, a uz primjenu kvantitativnih i kvalitativnih metoda. ${ }^{6}$ Upravljanje knjižničnim zbirkama uključuje niz važnih aktivnosti poput planiranja, postavljanja ciljeva, donošenja odluka, određivanja vrsta građe koja će biti nabavljena, određivanja financijskog proračuna, nabavu građe i njezino vrednovanje. ${ }^{78}$ Dodatne aktivnosti uključuju pregled svih ugovora o nabavi ili pristupu e-izvorima; upravljanje zbirkom na temelju izlučivanja, otkazivanje nabave, upravljanje pohranom i čuvanjem građe; pisanje i revidiranje pisanih smjernica razvoja zbirke; vrednovanje i procjenu zbirke i pratećih usluga, upotrebu zbirke i korisnička iskustva; rješavanje problema vezanih uz odabranu građu; oblikovanje veze $\mathrm{s}$ korisničkom zajednicom i pružanje usluga korisnicima koji ne mogu doći u knjižnicu; suradnju s drugim knjižničarima na razmjeni građe te kooperativni razvoj; traženje dodatnih financijskih sredstava za razvoj zbirki i upravljanje njome uz pomoć dotacija. ${ }^{9}$

Knjižničari koji se bave razvojem knjižničnih zbirki informacije nužne za svoj posao prikupljaju od kolega knjižničara, dobavljača građe, ali i od samih korisnika knjižnice. ${ }^{10}$ Korisnici svoje potrebe i želje za određenom knjižničnom građom jasno iskazuju tijekom sudjelovanja u istraživanjima njihovih stavova i potreba ili neposredno u kontaktu s knjižničnim osobljem prilikom dolaska u knjižnicu. Rezultat njihova sudjelovanja u razvoju zbirki jest nabava građe za koju korisnici očekuju da im bude dostupna prilikom njihova sljedećeg dolaska u knjižnicu. S obzirom na to da svaka knjižnica ima ograničen financijski proračun, „razvoj knjižničnih zbirki od knjižničara zahtijeva kombiniranje njihovog znanja o nekom tematskom području s razumijevanjem interesa korisnika imajući pritom na umu ograničenja proračuna knjižnice“ ${ }^{11}$ Korisnici knjižnice vrlo često nemaju cjelovi-

\footnotetext{
4 Gessesse, Kebede. Collection development and management in the twenty-first century with special reference to academic libraries: an overview. // Library Management 21, 7(2000), 365.

5 Johnson, Peggy. Nav. dj. Str. 2.

6 Rossmann, Doralyn. An Assessment of the relationships between resource development decisions, library collection usage, and user perceptions. // The Serials Librarian 65, 2(2013), 203.

7 Gessesse, Kebede. Nav. dj. Str. 365.

8 Isto.

9 Johnson, Peggy. Nav. dj. Str. 2-3.

10 Mangrum, Suzanne; Mary Ellen Pozzebon. Use of collection development policies in electronic resource management. // Collection Building 31, 3(2012), 108.

11 Mickelsen, Anna. Practice makes perfect. // Library Journal 141, 14(2016), 34.
} 
tu sliku stanja razvoja knjižničnih zbirki (ili ju nemaju uopće), ali očekuju da se poštuju njihove potrebe za građom u planovima nabave građe u knjižnici. To je ujedno realan, ali ne uvijek i realiziran, rezultat njihova utjecaja na razvoj zbirki jer knjižnice nisu u mogućnosti nabaviti svu građu ponuđenu na tržištu niti su u mogućnosti ispuniti sve želje i potrebe korisnika odjednom.

Bez obzira na spomenute probleme, korisnici žele znati da će njima zanimljiva građu biti dostupna za posudbu u knjižnici. ${ }^{12}$ Stoga se knjižničari koji rade na razvoju knjižničnih zbirki moraju rukovoditi kriterijima selekcije pri nabavi građe koji će uključivati građu koju veći broj korisnika želi imati dostupnu u trenutku sljedećeg dolaska u knjižnicu. ${ }^{13}$

Uz tradicionalnu tiskanu (papirnu) građu, fondu knjižnice potrebno je dodati i građu u digitalnom obliku. Ona predstavlja poseban problem u nabavi zbog činjenice da živimo u hibridnom svijetu paralelne upotrebe tiskane i digitalne građe i da je zbog toga u knjižnicama potrebno razmotriti različite načine rada korisnika s građom koji možda uključuju davanje prednosti jednoj, odnosno drugoj vrsti građe. ${ }^{14}$ Prema Magrum i Pozzebon dvije navedene vrste građe tvore dvije paradigme s kojima se knjižnice susreću svakodnevno: u dosadašnjoj paradigmi knjižnice i dalje moraju ispunjavati svoju ulogu kao fizički prostori i pružati osobne usluge te davati tiskanu građu na upotrebu kao što su to činile prije automatizacije svojeg poslovanja. Nova paradigma donosi nabavu digitalne građe i plaćanje licencija za pristup izvorima digitalne građe izvan knjižnice te pružanje pristupa tehnološkim istraživačkim alatima koji korisnicima mogu poslužiti u razne svrhe. ${ }^{15}$ Dio digitalnih sadržaja koji je zanimljiv korisnicima knjižnica dostupan je u slobodnom pristupu na internetu, bez troškova za knjižnicu. Knjižnice se ne bi trebale natjecati s internetom u količini sadržaja koje nude, već nuditi odabrane digitalne sadržaje lokalno, uz uslugu usmjeravanja korisnika prema odabranim informacijskim izvorima koje same ne mogu ponuditi, kao što su to činile i s tradicionalnom papirnom građom. Uz ponudu dijela sadržaja u digitalnom obliku, svakako je potrebno osigurati tehničke, financijske i ljudske preduvjete, što nije uvijek lako postići. Navedena literatura ukazuje na potrebu za sustavnim pristupom izgradnji knjižničnih zbirki i potrebno je pridržavati se preporuka koje su se pokazale kvalitetnima i provedivima u knjižničarskoj praksi. Posebnosti koje se pojavljuju prilikom razvoja knjižničnih zbirki potrebno je također sustavno opisivati kako bi knjižničarska javnost s njima bila upoznata.

Kada je riječ o istraživanjima korisnika knjižnica, često se spominje riječ zadovoljstvo. Zadovoljstvo korisnika knjižnicom općenito, njezinim fondom i usluga-

12 Isto.

13 Isto.

14 Cassell, Kay Ann. Interviews with collection development managers. // Collection Building 34, 4(2015), 135.

15 Mangrum, Suzanne; Mary Ellen Pozzebon. Nav. dj. Str. 108. 
ma nije lako postići. Čest kriterij za postizanje zadovoljstva jest korisnikova mogućnost samostalnog pronalaska građe u knjižnici ili pronalaska građe uz pomoć knjižničara. Ako je taj pronalazak rezultirao uspjehom jer je vrijednost knjižnične zbirke u očima korisnika proporcionalna lakoći pristupa uspješno pronađenoj gra${ } \mathrm{ii}^{16}$, tada će korisnik o knjižnici imati pozitivnu sliku, a ako je korisnik u potrazi bio neuspješan, tada će ta slika biti negativna. ${ }^{17}$ To su razlozi zbog kojih je korisnike potrebno stalno istraživati jer je potrebno saznati jesu li u svojoj potrazi za građom bili uspješni (a time i zadovoljni) i kakav je njihov pogled na knjižnični fond i usluge. Koliko je u tome uspjela Knjižnica i čitaonica Bogdana Ogrizovića, pokazat će rezultati istraživanja prikazani u nastavku rada.

\section{Istraživanje pogleda i stavova korisnika Knjižnice i čitaonice Bog- dana Ogrizovića u Zagrebu o fondu te knjižnice}

Kako bi knjižnica mogla uspješno planirati razvoj svojih zbirki i usluga, ona periodično mora provoditi istraživanja svojih korisnika. Istraživanje u ovom radu nastavak je ranijih istraživanja istih autora o položaju knjižnice u umreženom društvu $^{18}$ i percepciji korisnika o knjižnici i njenim uslugama. ${ }^{1920}$ Tuškan Mihočić pisala je o mjerenju uspješnosti poslovanja narodnih knjižnica te se u svojem radu osvrnula na pokazatelje uspješnosti poslovanja, od kojih je jedan postotak korištenog i nekorištenog fonda knjižnice. ${ }^{21}$ Nebesny i Švob napravile su pregled o izgradnji knjižne zbirke u narodnim knjižnicama. ${ }^{22}$ Novak se bavila analizom stanja razvoja narodnih knjižnica, pa je na primjeru nekoliko američkih i jedne hrvatske narodne knjižnice uočila probleme u njihovu razvoju izazvane recesijom, ali i zaključila kako su hrvatske narodne knjižnice po broju korisnika i načinima korištenja knjižničnih zbirki daleko od stagnacije. ${ }^{23}$ Cej, Grašić-Kvesić i Silić istraživali su učestalost korištenja audio-vizualne, multimedijske i elektroničke građe (AVME) te su zaključili kako se,

16 Soules, Aline. Collections, selection, access. // New Library World 115, 5-6(2014), 266.

17 Stoller, Michael. Nav. dj. Str. 5.

18 Vrana, Radovan; Jasna Kovačević. Položaj knjižnice u umreženom društvu. // Vjesnik bibliotekara Hrvatske 53, 3-4(2010), 25-41.

19 Vrana, Radovan; Jasna Kovačević. Percepcija korisnika o knjižnici i knjižničnim uslugama kao temelj marketinške strategije knjižnice. // Vjesnik bibliotekara Hrvatske 56, 3(2013), 23-46.

20 Vrana, Radovan; Jasna Kovačević. Pogled na knjižnične usluge iz perspektive korisnika. // Vjesnik bibliotekara Hrvatske 58, 1-2(2015), 135-160.

21 Tuškan Mihočić, Gorana. Mjerenje uspješnosti poslovanja u narodnoj knjižnici. // Vjesnik bibliotekara Hrvatske 54, 4(2011), 219.

22 Nebesny, Tatjana; Mira Švob. Izgradnja knjižne zbirke u narodnim knjižnicama. // Slobodan pristup informacijama u službi kulturnog razvitka: zbornik radova. Zagreb: Hrvatsko knjižničarsko društvo, 2002. Str. 56-75.

23 Novak, Helena. Narodne knjižnice i recesij - ili depresija? // Vjesnik bibliotekara Hrvatske 54, $4(2011), 225-252$. 
usprkos općoj dostupnosti AVME-sadržaja, usluge i zbirke odjela AVME-građe u narodnim knjižnicama i dalje koriste. ${ }^{24}$ Pejić je istraživao ulogu narodnih knjižnica i njihovih fondova u formalnom i neformalnom obrazovanju i istraživanjem je došao do podatka da je udio stručne/znanstvene knjige u sveukupnom fondu različit od knjižnice do knjižnice i da taj udio iznosi 37,02\% ukupnih fondova. ${ }^{25}$ Izvori znanstvenih informacija dio su istraživanja i u ovom radu. Navedeni radovi bili su poticaj za pokretanje novog istraživanja korisnika u Knjižnici i čitaonici Bogdana Ogrizovića u Zagrebu s ciljem prikupljanja podataka o pogledima i stavovima korisnika te knjižnice o njezinu fondu. Svrha istraživanja bila je pomoći procesu planiranja razvoja zbirki knjižnice na temelju podataka prikupljenih o pogledima i stavovima korisnika o fondu knjižnice. Temeljno pitanje istraživanja bilo je jesu li korisnici knjižnice zadovoljni dostupnošću građe u knjižnici. Istraživanje je provedeno uz pomoć tiskanog anketnog upitnika s ukupno 13 pitanja, od kojih je manji dio bio otvorenog tipa predviđenog za samostalan upis odgovora (anketni upitnik nalazi se $\mathrm{u}$ prilogu ovom radu). Prva dva pitanja od korisnika su tražila općenite podatke poput onih o spolu i postignutom ili trenutnom obrazovnom stupnju ispitanika. Sljedeća dva pitanja odnosila su se na učestalost dolaska u knjižnicu i vrijeme provedeno u knjižnici kao bitne kriterije zadovoljstva korisnika fondom knjižnice. Sljedećih pet pitanja odnosilo se na razloge dolaska u knjižnicu (upotrebu knjižnice), korištenje raznih vrsta građe (upotrebu fonda knjižnice) te želju korisnika za pojedinim vrstama građe, čime se željelo saznati više detalja o pogledima i stavovima korisnika o fondu knjižnice. Završna dva pitanja odnosila su se na zadovoljstvo dostupnošću pojedinih vrsta građe i želje korisnika za određenim vrstama građe s ciljem saznavanja zadovoljstva postojećim stanjem fonda knjižnice i mjerama nužnim za postizanje veće dostupnosti građe u knjižnici. U istraživanju je korišten prigodni uzorak, pa su u istraživanju mogli sudjelovati svi korisnici knjižnice (članovi i nečlanovi) koji su se u vrijeme istraživanja nalazili u knjižnici te zbog toga nije rađena posebna usporedba ispitanika u odnosu na broj i strukturu aktivnih članova knjižnice. Istraživanje je provedeno u razdoblju od 1. 7. 2016. do 24. 9. 2016., a u njemu je sudjelovalo ukupno 137 korisnika knjižnice (članova i nečlanova).

\subsection{Rezultati istraživanja i komentari rezultata}

U nastavku rada prikazani su rezultati provedenog istraživanja u tri cjeline: opći podaci o ispitanicima, upotreba knjižnice i upotreba fonda knjižnice te komentari predstavljenih rezultata.

24 Cej, Višnja; Tea Grašić-Kvesić; Tomislav Silić. Audiovizualna,mutimedijalna i elektronička građa: istraživanje učestalosti korištenja. // Vjesnik bibliotekara Hrvatske 56, 4(2013), 145-168.

25 Pejić, Ilija. Narodne knjižnice: potpora formalnom i neformalnom obrazovanju - visoko obrazovanje. // Radovi Zavoda za znanstvenoistraživački i umjetnički rad u Bjelovaru 3(2009), 97-112. 


\subsubsection{Opći podaci o ispitanicima}

\section{Struktura ispitanika prema spolu}

Prema odgovorima ispitanika, u istraživanju je sudjelovalo 98 (71,53\%) osoba ženskog spola i 39 (28,47\%) osoba muškog spola, što čini ukupno 137 ispitanika.

\section{Dob i obrazovni stupanj ispitanika}

U sljedeća dva pitanja od ispitanika je zatraženo da sami upišu svoju dob i obrazovni status / stupanj obrazovanja (tablica 1). Pojedini ispitanici nisu označili svoju dob, ali su označili obrazovni status / stupanj obrazovanja. Među ispitanicima najviše je korisnika knjižnice u dobnoj skupni od 20 do 29 godina starosti, među kojima je najviše onih sa završenom srednjom školom, statusom studenta, ali i onih koji su završili studij. Sljedeća velika skupina korisnika jesu oni u dobi od 30 do 39 godina i među njima je najviše onih koji su završili studij, a slijede ih oni sa završenom srednjom školom, dok su u toj skupini i dva doktora znanosti. Treća skupina korisnika jesu korisnici u dobi od 10 do 19 godina, među kojima je najviše učenika, a slijede korisnici sa završenom srednjom školom i jedan student. Preostale dobne skupine manje su zastupljene brojem ispitanika. Iz rezultata je moguće iščitati kako se u knjižnici najviše zadržavaju korisnici mlađe dobi, dok ih slijede osobe srednje dobi i najmanje osoba treće dobi.

Tablica 1. Dob i trenutni ili postignuti obrazovni stupanj ispitanika $(\mathrm{N}=129)$

\begin{tabular}{|c|c|c|c|c|c|c|c|c|c|}
\hline 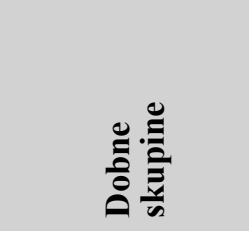 & $\mathbf{z}$ & 宽 & 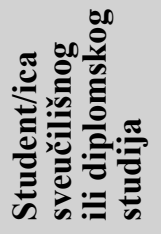 & $\ddot{n}$ & 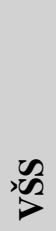 & $\underset{⿱ n}{\infty}$ & 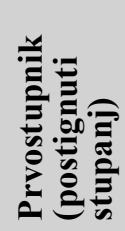 & $\begin{array}{l}\dot{0} \\
\dot{\Sigma}\end{array}$ & $\begin{array}{l}\dot{0} \\
\dot{\Delta}\end{array}$ \\
\hline $10-19$ & 13 & 7 & 1 & 5 & 0 & 0 & 0 & 0 & 0 \\
\hline $20-29$ & 66 & 0 & 22 & 21 & 2 & 19 & 1 & 1 & 0 \\
\hline $30-39$ & 26 & 0 & 0 & 4 & 2 & 18 & 0 & 0 & 2 \\
\hline $40-49$ & 11 & 0 & 0 & 2 & 0 & 7 & 0 & 1 & 1 \\
\hline $50-59$ & 6 & 0 & 0 & 2 & 0 & 4 & 0 & 0 & 0 \\
\hline $60-69$ & 2 & 0 & 0 & 0 & 0 & 0 & 0 & 0 & 2 \\
\hline $70-79$ & 1 & 0 & 0 & 0 & 0 & 1 & 0 & 0 & 0 \\
\hline Bez oznake dobi & 4 & 0 & 0 & 0 & 1 & 2 & 0 & 0 & 1 \\
\hline Ukupno & 129 & 7 & 23 & 34 & 5 & 51 & 1 & 2 & 4 \\
\hline
\end{tabular}




\section{Učestalost dolaska ispitanika u knjižnicu}

U ovom pitanju od ispitanika je zatražen odgovor o učestalosti dolaska u knjižnicu, važnom faktoru upravljanja knjižnicom zbog mogućnosti da se korisnici upoznaju sa što više knjižničnih usluga i fondom knjižnice te na temelju tih iskustava pruže što kvalitetnije odgovore $u$ istraživanjima korisnika o navedena dva segmenta upravljanja knjižnicom. Odgovori na to pitanje (tablica 2.) pokazuju da gotovo polovica ispitanika (47,79\%) dolazi u knjižnicu više puta tjedno, što predstavlja izvrstan rezultat i visoku zainteresiranost ispitanika za ponudu knjižnice (fond i usluge). Manji broj ispitanika (6,6\%) dolazi u knjižnicu manje od jednom mjesečno. Zbog ograničenosti ankete $u$ broju pitanja (kako se ispitanike prevelikim brojem pitanja ne bi odbilo od sudjelovanja u istraživanju), ovom prigodom nisu ispitivani razlozi rjeđeg dolaska ispitanika u knjižnicu.

Tablica 2. Učestalost dolaska ispitanika u knjižnicu $(\mathrm{N}=136)$

\begin{tabular}{|c|c|c|c|c|c|c|c|c|}
\hline & 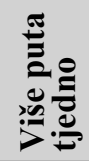 & 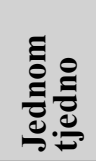 & 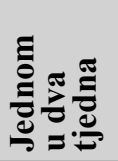 & 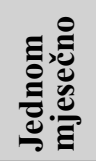 & 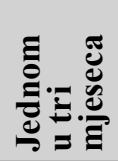 & 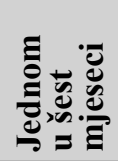 & 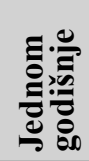 & $\frac{\stackrel{\Xi}{\bar{E}}}{\stackrel{\bar{E}}{5}}$ \\
\hline $\mathrm{N}$ & 65 & 18 & 30 & 14 & 5 & 1 & 3 & 136 \\
\hline$\%$ & 47,79 & 13,26 & 22,06 & 10,29 & 3,67 & 0,73 & 2,20 & $100 \%$ \\
\hline
\end{tabular}

U nastavku prikaza rezultata istraživanja korisnika dani su podaci o učestalosti dolaska ispitanika u knjižnicu prema dobnoj i obrazovnoj strukturi sa svrhom dobivanja detaljnijeg uvida u karakteristike ispitanika.

\section{UPOTREBA KNJIŽNICE}

Učestalost dolaska ispitanika u knjižnicu prema dobnoj strukturi

Pregled učestalosti dolaska u knjižnicu prema dobnoj skupini (tablica 3.) ukazuje na češći dolazak korisnika u dobnim skupinama 20-29 i 30-39 godina u odnosu na druge dobne skupine ispitanika.

Tablica 3. Učestalost dolaska ispitanika u knjižnicu prema dobnoj strukturi

\begin{tabular}{|c|c|c|c|c|c|c|c|c|}
\hline 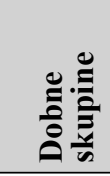 & 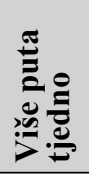 & 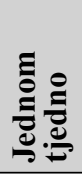 & 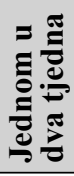 & 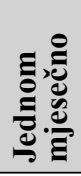 & 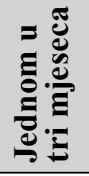 & 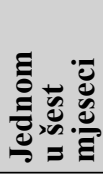 & 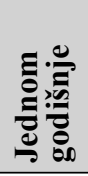 & 产 \\
\hline 10-19 & 6 & 1 & 3 & 2 & 0 & 0 & 0 & 12 \\
\hline $20-29$ & 37 & 9 & 13 & 5 & 2 & 1 & 3 & 70 \\
\hline
\end{tabular}




\begin{tabular}{|c|c|c|c|c|c|c|c|c|}
\hline 总关 & 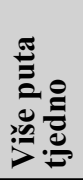 & 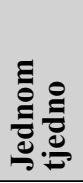 & 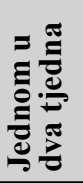 & 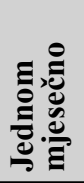 & 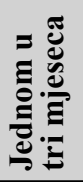 & 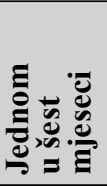 & 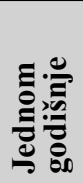 & 這 \\
\hline 30-39 & 10 & 2 & 8 & 4 & 1 & 0 & 0 & 25 \\
\hline $40-49$ & 3 & 1 & 6 & 1 & 0 & 0 & 0 & 11 \\
\hline $50-59$ & 3 & 1 & 0 & 1 & 2 & 0 & 0 & 7 \\
\hline $60-69$ & 2 & 0 & 0 & 0 & 0 & 0 & 0 & 2 \\
\hline $70-79$ & 0 & 1 & 0 & 0 & 0 & 0 & 0 & 1 \\
\hline Ukupno & 61 & 15 & 30 & 13 & 5 & 1 & 3 & 128 \\
\hline
\end{tabular}

Učestalost dolaska ispitanika u knjižnicu prema obrazovnoj strukturi

Prema obrazovnoj strukturi (tablica 4.), u knjižnicu najčešće dolaze osobe s visokom stručnom spremom (završenim fakultetskim obrazovanjem), a slijede ih osobe sa srednjom stručnom spremom te studenti (koji svoj boravak u knjižnici koriste za rad u čitaonici).

Tablica 4. Učestalost dolaska ispitanika u knjižnicu prema obrazovnoj strukturi

\begin{tabular}{|c|c|c|c|c|c|c|c|c|}
\hline 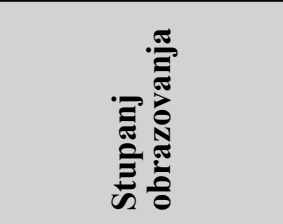 & 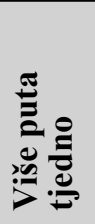 & ฏ。 & 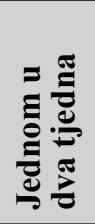 & 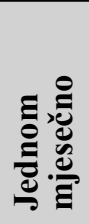 & 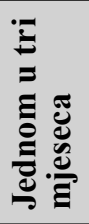 & 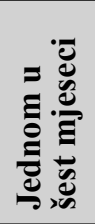 & 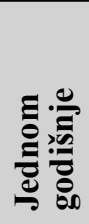 & 音 \\
\hline Učenik/ica & 4 & 0 & 2 & 1 & 0 & 0 & 0 & 7 \\
\hline $\begin{array}{l}\text { Student/ica } \\
\text { sveučilišnog ili } \\
\text { diplomskog studija }\end{array}$ & 15 & 2 & 4 & 1 & 0 & 0 & 0 & 22 \\
\hline SSS & 22 & 6 & 5 & 4 & 1 & 1 & 2 & 41 \\
\hline VŠS & 1 & 0 & 2 & 1 & 1 & 0 & 0 & 5 \\
\hline $\begin{array}{l}\text { Prvostupnik } \\
\text { (postignuti stupanj) }\end{array}$ & 1 & 0 & 0 & 0 & 0 & 0 & 0 & 1 \\
\hline VSS & 18 & 8 & 15 & 7 & 3 & 0 & 1 & 52 \\
\hline Magistar & 1 & 1 & 0 & 0 & 0 & 0 & 0 & 2 \\
\hline
\end{tabular}




\begin{tabular}{|c|c|c|c|c|c|c|c|c|}
\hline 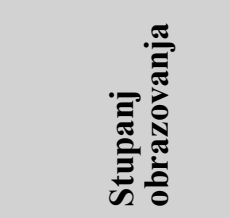 & 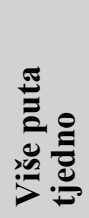 & 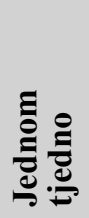 & = & 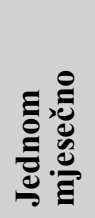 & 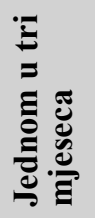 & 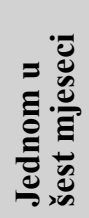 & 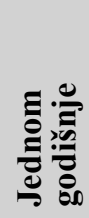 & $\stackrel{\varrho}{\stackrel{\Xi}{E}}$ \\
\hline Doktor znanosti & 3 & 1 & 1 & 0 & 0 & 0 & 0 & 5 \\
\hline Bez oznake & 0 & 0 & 1 & 0 & 0 & 0 & 0 & 1 \\
\hline Ukupno & 65 & 18 & 30 & 14 & 5 & 1 & 3 & 136 \\
\hline
\end{tabular}

Vrijeme provedeno u knjižnici

Pitanjem o vremenu provedenom u knjižnici željelo se utvrditi zanimanje korisnika za knjižnicu kao prostor pogodan za dulji boravak radi korištenja fonda i usluga knjižnice. U odgovorima na to pitanje u ukupnom broju od 136 ispitanika koji su odgovorili na njega moguće je primijetiti dvije skupine korisnika knjižnice koje se posebno ističu. Prva skupina, odnosno $32,36 \%$ ispitanika $(\mathrm{N}=44)$, u knjižnici boravi vrlo kratko, do pola sata. To je vrijeme dovoljno za pregledavanje trenutne ponude informacija u knjižnici, kao i za pronalazak i posudbu knjiga. Sljedeća skupina ispitanika, njih 27,94\% $(\mathrm{N}=38)$, u knjižnici boravi dulje od tri sata. Slijedi boravak do jednog sata $(16,91 \%$ ispitanika, $\mathrm{N}=23)$, potom boravak do tri sata $(14,70 \%$ ispitanika, $\mathrm{N}=20)$ te boravak do dva sata $(8,09 \%$ ispitanika, $\mathrm{N}=11)$. Iz podataka o dobnoj strukturi ispitanika vidljivo je kako je riječ o studentima koji knjižnicu koriste za učenje, pa je njihov boravak u prostoru knjižnice znatno dulji od boravka preostalih skupina ispitanika.

Broj knjiga koje ispitanici posuđuju prilikom jednog posjeta knjižnici.

Broj knjiga posuđenih tijekom jednog posjeta knjižnici važan je indikator zanimanja korisnika za fond knjižnice. Iz odgovora na pitanje o broju posuđenih knjiga prilikom jednog posjeta knjižnici proizašlo je da je prosječan broj knjiga koje korisnici posuđuju prilikom jednog posjeta knjižnici 2,11 (median: 2). Dobivena vrijednost trebala bi biti uspoređena s drugim narodnim knjižnicama u Republici Hrvatskoj. Dobivena vrijednost također govori o primjerenosti trajanja (roka) posudbe. U Knjižnici i čitaonici Bogdana Ogrizovića u kojoj je provedeno istraživanje, a koja djeluje u sklopu sustava Knjižnica Grada Zagreba, rok posudbe knjiga je 21 dan (dok je ljeti taj rok 63 dana), što korisniku daje dovoljno vremena za čitanje posuđenih naslova. ${ }^{26}$

26 Upisi i posudba. [citirano: 2016-10-23] Dostupno na http://www.kgz.hr/hr/informacije/upisi-i-posudba-196/196. 
Razlozi dolaska ispitanika u knjižnicu

U ovom pitanju od ispitanika se tražilo da označe odgovore koji najbolje opisuju razloge njihova dolaska u knjižnicu. U prethodnim istraživanjima provedenim $2013 .{ }^{27}$, i $2015 .{ }^{28}$ godine bilo je razvidno kako je glavni razlog dolaska u knjižnicu posudba knjiga, pa to pitanje u ovom istraživanju više nije postavljano jer se posudba smatra temeljnom uslugom knjižnice. Razlozi dolaska u knjižnicu važan su pokazatelj knjižničarima u upravljanju knjižnicom i planiranju njezina razvoja. Odgovori na to pitanje ukazuju na povezanost dolaska korisnika knjižnice i aktivnosti vezanih uz obrazovanje (posudbu građe povezanu s obrazovanjem) i učenje uz dulji boravak u knjižnici s duljinom boravka u knjižnici u prethodnom pitanju. Odgovori također ukazuju na prioritete koje korisnici imaju prilikom dolaska u knjižnicu. Obrazovanje je, bilo ono formalno, neformalno ili informalno, važna aktivnost koja privlači korisnike Knjižnice i čitaonice Bogdana Ogrizovića koji su sudjelovali u istraživanju, a koji prostor knjižnice koriste za aktivnosti povezane s vlastitim obrazovanjem, učenjem $i$ istraživanjem. U tom segmentu istraživanja posebno su se istaknule dvije dobne skupine (tablica 3.), skupina od 20 do 29 godina starosti i skupina od 30 do 39 godina starosti, kao i dvije obrazovne skupine (tablica 4.) - studenti i ispitanici koji imaju visoku školsku spremu (VSS). Potrebno je naglasiti kako knjižnica također tradicionalno služi studentima kao prostor za učenje te je već godinama popularna među studentskom populacijom. Razlozi poput samostalnog istraživanja raznih tema, hobija i pronalaska praktičnih informacija temelj su rada knjižnica, a njihov se poredak mijenjao s razvojem informacijske i komunikacijske tehnologije i dostupnošću informacija na internetu. Zabava i hobi također su važni elementi programa aktivnosti u knjižnicama, a Knjižnica i čitaonica Bogdana Ogrizovića nalazi se u samom središtu Zagreba i popularno je mjesto održavanja različitih događaja povezanih s područjem kulture. Potraga za informacijama potrebnim za obavljanje posla također je česta aktivnost u knjižnicama, ali nije toliko zastupljena među korisnicima knjižnice. Svi navedeni razlozi pomažu u selekciji građe prilikom njezine nabave. U istraživanju su prikupljeni sljedeći razlozi dolaska u knjižnicu (višestruki odgovori): aktivnost povezana s vlastitim obrazovanjem (formalnim i neformalnim) $(\mathrm{N}=84)$, učenje uz dulji boravak u prostorima knjižnice (učenici i studenti) $(\mathrm{N}=81)$, istraživanje (općenito) $(\mathrm{N}=49)$, zabava $(\mathrm{N}=43)$ i hobi $(\mathrm{N}=41)$.

$\mathrm{U}$ nastavku prikaza odgovora predstavljeni su razlozi dolaska ispitanika u knjižnicu prema dobnoj i obrazovnoj strukturi radi stjecanja boljeg uvida u karakteristike ispitanika s obzirom na to pitanje.

27 Vrana, Radovan; Jasna Kovačevića. Percepcija. Nav. dj.

28 Vrana, Radovan; Jasna Kovačević. Pogled. Nav. dj. 
Razlozi dolaska ispitanika u knjižnicu prema dobnoj strukturi

Tablica 5. Razlozi dolaska ispitanika u knjižnicu prema dobnoj strukturi (višestruki odgovori)

\begin{tabular}{|l|c|c|c|c|c|c|c|}
\hline & \multicolumn{7}{|c|}{ Dobne skupine } \\
\hline & $\mathbf{1 0 - 1 9}$ & $\mathbf{2 0 - 2 9}$ & $\mathbf{3 0 - 3 9}$ & $\mathbf{4 0 - 4 9}$ & $\mathbf{5 0 - 5 9}$ & $\mathbf{6 0 - 6 9}$ & $\mathbf{7 0 - 7 9}$ \\
\hline $\begin{array}{l}\text { Aktivnost povezana s } \\
\text { vlastitim obrazovanjem } \\
\text { (formalnim i } \\
\text { neformalnim) }\end{array}$ & 5 & 52 & 13 & 3 & 4 & 2 & 1 \\
\hline $\begin{array}{l}\text { Učenje uz dulji boravak } \\
\text { u prostorima knjižnice }\end{array}$ & 7 & 53 & 8 & 5 & 5 & 0 & 0 \\
\hline Istraživanje (općenito) & 6 & 15 & 12 & 7 & 4 & 1 & 1 \\
\hline Zabava & 7 & 14 & 9 & 7 & 2 & 1 & 0 \\
\hline Hobi & 7 & 17 & 12 & 3 & 2 & 0 & 0 \\
\hline Kulturni događaji & 1 & 8 & 7 & 4 & 4 & 0 & 1 \\
\hline $\begin{array}{l}\text { Pronalazak praktičnih } \\
\text { informacija }\end{array}$ & 1 & 10 & 2 & 3 & 1 & 0 & 0 \\
\hline Posao & 34 & 1 & 5 & 5 & 3 & 1 & 0 \\
\hline
\end{tabular}

Razlozi dolaska ispitanika u knjižnicu prema obrazovnoj strukturi

Tablica 6. Razlozi dolaska ispitanika u knjižnicu prema obrazovnoj strukturi (višestruki odgovori)

\begin{tabular}{|c|c|c|c|c|c|c|c|c|c|}
\hline & \multicolumn{9}{|c|}{ Trenutni obrazovani stupanj } \\
\hline & لֶّ & 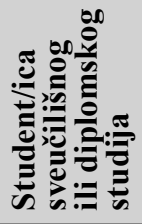 & ஸे & $\stackrel{\infty}{>}$ & 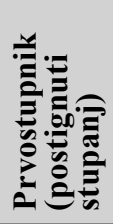 & $\stackrel{\infty}{\infty}$ & $\begin{array}{l}\dot{j} \\
\dot{\Xi} \\
\dot{\Sigma}\end{array}$ & $\begin{array}{l}\dot{0} \\
\dot{\overrightarrow{0}}\end{array}$ & 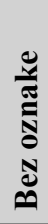 \\
\hline $\begin{array}{l}\text { Aktivnost povezana s } \\
\text { vlastitim obrazovanjem } \\
\text { (formalnim i } \\
\text { neformalnim) }\end{array}$ & 2 & 15 & 28 & 2 & 1 & 32 & 2 & 2 & 0 \\
\hline $\begin{array}{l}\text { Učenje uz dulji boravak } \\
\text { u prostorima knjižnice } \\
\text { (učenici i studenti) }\end{array}$ & 3 & 20 & 33 & 2 & 0 & 19 & 2 & 1 & 1 \\
\hline
\end{tabular}




\begin{tabular}{|c|c|c|c|c|c|c|c|c|c|}
\hline & \multicolumn{9}{|c|}{ Trenutni obrazovani stupanj } \\
\hline & : & 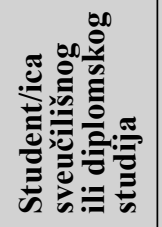 & $\mathscr{n}$ & $\stackrel{\infty}{>}$ & 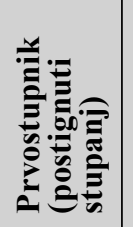 & $\underset{>}{\infty}$ & $\begin{array}{l}\dot{0} \\
\dot{\Sigma} \\
\dot{\Sigma}\end{array}$ & $\begin{array}{l}\dot{0} \\
\dot{\vec{\Delta}} \\
\dot{\Delta}\end{array}$ & 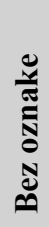 \\
\hline $\begin{array}{l}\text { Istraživanje } \\
\text { (općenito) }\end{array}$ & 3 & 3 & 11 & 1 & 0 & 25 & 2 & 3 & 1 \\
\hline Zabava & 4 & 4 & 9 & 2 & 0 & 19 & 0 & 4 & 1 \\
\hline Hobi & 5 & 5 & 8 & 2 & 1 & 18 & 0 & 2 & 0 \\
\hline $\begin{array}{l}\text { Kulturni } \\
\text { događaji }\end{array}$ & 1 & 3 & 4 & 3 & 0 & 13 & 1 & 2 & 1 \\
\hline $\begin{array}{l}\text { Pronalazak } \\
\text { praktičnih informacija }\end{array}$ & 0 & 3 & 6 & 0 & 0 & 8 & 0 & 1 & 0 \\
\hline Posao & 18 & 53 & 1 & 1 & 0 & 11 & 1 & 2 & 0 \\
\hline Ukupno & & & & & & & & & \\
\hline
\end{tabular}

Odgovori u tablicama 5. i 6. iznova pokazuju da u knjižnicu dolaze korisnici mlađe dobi i da je glavni razlog dolaska u knjižnicu obrazovanje te da u aktivnostima obrazovanja najviše sudjeluju ispitanici s visokom školskom spremom, koje slijede ispitanici sa srednjom školom i studenti, dok knjižnicu za učenje koriste ispitanici sa srednjom školom, studenti i ispitanici s visokom školskom spremom. Ispitanici s visokom školskom spremom najzastupljeniji su i u drugim razlozima dolaska u knjižnicu. Rezultati pokazuju da knjižnica svojom ponudom usluga i fondom uspješno zadovoljava informacijske i druge potrebe korisnika različitih dobnih skupina i obrazovne strukture.

\section{Upotreba fonda knjižnice}

Vrste građe koju ispitanici žele imati na raspolaganju

Ovo pitanje otvara mogućnost da korisnici izraze svoje želje i potrebe za određenim vrstama građe. Odgovori na to pitanje (tablica 7.) imaju utjecaj na nabavu knjižnične građe. Među rezultatima se, uz književnost i publicistiku, posebno ističe želja i potreba korisnika za znanstvenim informacijama u digitalnom i papirnatom obliku, koje narodne knjižnice nužno ne nabavljaju u velikom opsegu, ali ih ipak nude kako bi popularizirale znanost. Među željenom građom nalaze se i knjige na stranim jezicima, ali i enciklopedije, unatoč dostupnosti mnogih informacija putem interneta. Slijede časopisi i novine, koji su dostupni u knjižnici 
u određenom opsegu u tiskanom formatu. Uskoro će knjižnica biti u mogućnosti ponuditi i časopise na stranim jezicima (u ovom slučaju na engleskom jeziku, a u planu su i časopisi na drugim svjetskim jezicima) u većem broju (15 časopisa) i u digitalnom formatu, što će privući nove korisnike u knjižnicu. ${ }^{29}$ Zanimljivo je i malo zanimanje korisnika knjižnice za informacije iz lokalne zajednice premda se narodne knjižnice trude biti središta lokalne zajednice.

Tablica 7. Vrste građe koju korisnici žele imati na raspolaganju (višestruki odgovori)

\begin{tabular}{|l|l|}
\hline & N \\
\hline Knjige - književnost na hrvatskom jeziku & 93 \\
\hline Knjige - književnost na stranim jezicima & 76 \\
\hline Znanstvene informacije dostupne u knjižnici putem interneta & 47 \\
\hline Znanstvene informacije dostupne u papirnatom obliku & 46 \\
\hline Knjige - publicistika na stranim jezicima & 45 \\
\hline Knjige - publicistika na hrvatskom jeziku & 42 \\
\hline Enciklopedije & 38 \\
\hline Udžbenici & 37 \\
\hline Časopisi na stranim jezicima & 34 \\
\hline Časopisi na hrvatskom jeziku & 33 \\
\hline Novine na stranim jezicima & 28 \\
\hline Novine na hrvatskom jeziku & 27 \\
\hline Časopisi na hrvatskom jeziku & 21 \\
\hline Poslovne informacije & 15 \\
\hline Službene (državne) informacije & 13 \\
\hline Slikovnice & 11 \\
\hline Informacije iz lokalne zajednice & 7 \\
\hline
\end{tabular}

29 Lechpammer, Stela. Besplatno čitanje američkog tiska na tabletima u čitaonici. [citirano: 2016-10-30]. Dostupno na http://www.vecernji.hr/zg-zivot/i-doma-ce-se-moci-citati-strana-online-izdanja-1124481. 
Razlozi čitanja knjiga i časopisa dostupnih u knjižnici

U sljedeća dva pitanja ispitanici su bili upitani o razlozima čitanja knjiga i časopisa dostupnih u knjižnici u kojoj je provedeno istraživanje sa svrhom određivanja vrste knjiga i časopisa za nabavu. Razlozi za odabir te dvije vrste publikacija redoslijedom (po važnosti) (tablica 8.) su slični: knjige i časopisi najviše su čitani zbog osobnog zadovoljstva, zatim u svrhu obrazovanja i osobnog razvoja, nakon čega slijede drugi razlozi. Popularnost vlastitog zadovoljstva i osobnog razvoja sugerira prepoznavanje knjižnice kao (barem dijela) trećeg prostora za određene kategorije korisnika.

Tablica 8. Razlozi čitanja knjiga i časopisa dostupnih u knjižnici (višestruki odgovori)

\begin{tabular}{|l|c|c|}
\hline & Knjige & Časopisi \\
\hline Vlastito zadovoljstvo & 114 & 55 \\
\hline Posao & 23 & 12 \\
\hline Obrazovanje (škola, fakultet) & 87 & 43 \\
\hline Istraživanje & 39 & 32 \\
\hline Osobni razvoj & 69 & 37 \\
\hline Hobi & 38 & 16 \\
\hline Zabava & 44 & 25 \\
\hline $\begin{array}{l}\text { Neki drugi razlog, navedite } \\
\text { koji }\end{array}$ & $\begin{array}{l}\text { Da naučim } \\
\text { bolje čitati }\end{array}$ & $\begin{array}{l}\text { Ne čitam časopise; Ne čitam žuti } \\
\text { tisak; Uglavnom ne čitam časopise }\end{array}$ \\
\hline
\end{tabular}

Zadovoljstvo ispitanika dostupnošću vrsta građe

Pitanjem o zadovoljstvu korisnika dostupnošću građe željelo se dobiti odgovore koji će biti indikator zadovoljenja potreba korisnika za određenim vrstama građe. Odgovori prikupljeni u tom pitanju (tablica 9.) ukazuju na zadovoljstvo ispitanika u vezi s knjigama i novinama, dok su tek nešto slabije zadovoljstvo pokazali u vezi s časopisima, udžbenicima i enciklopedijama. S obzirom na to da narodna knjižnica mora voditi računa o korisnicima u svim dobnim i obrazovnim strukturama, pokazani stupanj zadovoljstva pojedinim vrstama građe očekivan je i s obzirom na upotrebu pojedine vrste građe u knjižnici, dok su u slučaju digitalne građe ocjene više od očekivanih s obzirom na problem nabave digitalne građe $u$ narodnim knjižnicama i omogućavanje korisnicima da joj pristupe i da ju koriste. 
Tablica 9. Zadovoljstvo ispitanika dostupnošću građe $(1=$ najniža ocjena, $5=$ najviša ocjena) $(\mathrm{N}=137)$

\begin{tabular}{|l|c|c|c|c|c|}
\hline & $\mathbf{1}$ & $\mathbf{2}$ & $\mathbf{3}$ & $\mathbf{4}$ & $\mathbf{5}$ \\
\hline Knjige (bez obzira na jezik i žanr) & 1 & 0 & 19 & 54 & 63 \\
\hline Časopisi (bez obzira na jezik) & 2 & 8 & 41 & 46 & 36 \\
\hline Novine (bez obzira na jezik) & 4 & 9 & 27 & 48 & 37 \\
\hline Digitalna građa & 5 & 10 & 37 & 40 & 34 \\
\hline Udžbenici, priručnici & 4 & 9 & 30 & 44 & 45 \\
\hline Enciklopedije, leksikoni & 2 & 4 & 23 & 44 & 55 \\
\hline Rječnici & 1 & 3 & 15 & 52 & 61 \\
\hline
\end{tabular}

Želje korisnika za potencijalno korisnom građom $(\mathrm{N}=136)$

Pitanje je postavljeno ispitanicima radi utvrđivanja njihove želje za tiskanom, odnosno digitalnom građom. Većina je ispitanika $(\mathrm{N}=105,77,21 \%)$ navela da preferira tiskanu, a tek nešto manje od četvrtine $(\mathrm{N}=31,22,79 \%)$ istaknulo je da preferira digitalnu građu. To pitanje važno je i zbog povezivanja knjižnice primarno s knjigama, a ne nekom drugom vrstom građe. ${ }^{30} \mathrm{U}$ budućnosti će biti potrebno ponoviti istraživanje zadovoljstva korisnika knjižnim fondom (i uslugama knjižnice) i u to će istraživanje svakako biti potrebno uključiti i ovo pitanje jer je za očekivati da će digitalna građa postati dostupnijom u knjižnici u odnosu na sadašnje stanje.

Stavovi ispitanika o knjižničnoj građi

Stavovi ispitanika o knjižničnoj građi važni su za otkrivanje problema u izboru, organizaciji i dostupnosti građe u knjižnici. Iz odgovora prikupljenih u tom pitanju (tablica 10.) vidljiv je visok stupanj zadovoljstva ispitanika građom dostupnom u knjižnici s obzirom na kriterije informacijskih, kulturnih i obrazovnih potreba. Mogućnost lakog pronalaženja građe u knjižnici ukazuje na dobar raspored građe u knjižnici. Ipak dio ispitanika tvrdi da ne uspijeva pronaći građu jer knjižnični katalog nudi podatke o građi, ali ju korisnici sami ne uspijevaju pronaći u knjižnici. U knjižnici je uvijek moguće dodati dodatne oznake građe na policama radi lakšeg snalaženja korisnika imajuću na umu fizička ograničenja prostora knjižnice koji određuje količinu i raspored svih predmeta u knjižnici te mogućnosti pružanja pojedinih knjižničnih usluga. Nadalje, dio ispitanika očekuje dostupnost željene građe u knjižnici, što također ovisi o prostoru knjižnice i njezinu financijskom proračunu.

30 Mickelsen, Anna. Nav. dj. Str. 36. 
Tablica 10. Stavovi ispitanika o knjižničnoj građi $(1=$ ne slažem se u potpunosti, 5 = slažem se u potpunosti).

\begin{tabular}{|l|c|c|c|c|c|}
\hline & $\mathbf{1}$ & $\mathbf{2}$ & $\mathbf{3}$ & $\mathbf{4}$ & $\mathbf{5}$ \\
\hline Građa odgovara mojim informacijskim potrebama & 2 & 2 & 19 & 55 & 52 \\
\hline Građa je adekvatna mojim kulturnim potrebama & 1 & 1 & 15 & 51 & 61 \\
\hline Građa je adekvatna mojim obrazovnim potrebama & 1 & 7 & 28 & 41 & 52 \\
\hline Građa je recentna (novijeg datuma) & 9 & 9 & 28 & 59 & 31 \\
\hline Građu je u knjižnici lako pronaći & 2 & 8 & 31 & 49 & 40 \\
\hline Obično uspijevam pronaći građu koju tražim & 4 & 11 & 29 & 53 & 33 \\
\hline Ne uspijevam pronaći građu jer ju knjižnica nema & 20 & 44 & 35 & 24 & 5 \\
\hline $\begin{array}{l}\text { Ne uspijevam pronaći građu jer su svi primjerci } \\
\text { posuđeni }\end{array}$ & 9 & 30 & 33 & 37 & 20 \\
\hline $\begin{array}{l}\text { Ne uspijevam pronaći građu jer knjižnica nema } \\
\text { dovoljan broj primjeraka građe }\end{array}$ & 14 & 35 & 29 & 28 & 22 \\
\hline $\begin{array}{l}\text { Ne uspijevam pronaći građu jer knjižnični katalog } \\
\text { nudi podatke o građi, ali ju ne mogu pronaći u } \\
\text { knjižnici }\end{array}$ & 42 & 34 & 26 & 13 & 13 \\
\hline
\end{tabular}

\section{Zaključak}

Razvoj knjižnih zbirki jedna je od najvažnijih trajnih aktivnosti u knjižnici. Premda su potrebe i želje pojedinih kategorija korisnika za građom velike, knjižnica se mora truditi zadovoljiti potrebe i želje za građom raznih kategorija korisnika uzimajući u obzir prostorna, ljudska i financijska ograničenja te ograničenja ponude na tržištu knjižnične građe (općenito). Bez obzira na prepreke i ograničenja u nabavi građe zbog kojih knjižnice ponekad moraju odustati od dijelova svojih planova, i nadalje je potrebno provoditi istraživanja korisnika s ciljem prikupljanja podataka koji će knjižnici pomoći u donošenju kvalitetnijih odluka u procesu nabave građe. Takav način rada nužno mora biti trajnom orijentacijom knjižnice, čime se postiže veća kvaliteta u razvoju pojedinih knjižničnih zbirki, fonda u cjelini i usluga knjižnice. Rezultati provedenog istraživanja ukazuju na područja većeg ili manjeg zadovoljstva korisnika fondom knjižnice. U prvom slučaju riječ je o potvrdi ispravnog smjera izgradnje fonda knjižnice, dok je u drugom slučaju riječ 
o pokazatelju segmenata rada knjižnice koji zahtijevaju korekcije. Promatrani u cjelini, rezultati istraživanja provedeni za potrebe ovoga rada ukazali su na jasne poglede i stavove korisnika Knjižnice i čitaonice Bogdana Ogrizovića u Zagrebu o fondu knjižnice, čime je odgovoreno na glavno pitanje istraživanja o zadovoljstvu korisnika dostupnošću građe u knjižnici. Knjige i dalje predstavljaju glavni predmet zanimanja korisnika, ali korisnici na raspolaganju žele imati i znanstvene informacije dostupne putem interneta, što jest svojevrsno iznenađenje jer je istraživanje provedeno u narodnoj knjižnici. Uočena je i velika učestalost dolazaka korisnika mlađe i srednje dobi u knjižnicu više puta tjedno. Važno je napomenuti i da je u istraživanju sudjelovao i određeni broj ispitanika koji su svoj odgovor o učestalosti boravka dali u kategoriji više puta tjedno (tu bismo kategoriju korisnika čak mogli istaknuti iznad kategorije koju bismo nazvali redovitim korisnicima) i koji imaju najjasniji pogled na fond, ali i usluge knjižnice i promjene koje se zbivaju u njoj. Njihov čest boravak u knjižnici najbolje govori o kvaliteti izgradnje njezina fonda. Dok dio korisnika u knjižnici boravi vrlo kratko (do pola sata), slijedi ih dio korisnika koji u knjižnici borave više sati i ti su korisnici detaljnije upoznati s ponudom građe u knjižnici. Korisnici građu najčešće koriste za potrebe vlastitog čitateljskog zadovoljstva, ali i za potrebe obrazovanja. Njihovi su pogledi i stavovi o građi dostupnoj u knjižnici jasni te su potvrdili kako knjižnična građa odgovara njihovim informacijskim, kulturnim i obrazovnim potrebama. Posljednje pitanje $u$ istraživanju ukazuje na problem nedostatka građe u knjižnici kao važan razlog nemogućnosti pronalaska građe. Sveukupno, rezultati istraživanja ukazuju na veliko zanimanje korisnika za knjižnicu, u prvom redu korisnika mlađe dobi, koji su ujedno u najvećem broju sudjelovali u istraživanju. Takav rezultat vrlo je važan za budućnost knjižnice jer su mlađe generacije privučene drugim medijima, pa im odlazak u knjižnicu ne mora biti među prioritetima. ${ }^{31}$ Rezultati provedenog istraživanja predstavljaju smjernice za daljnje postupanje u izgradnji knjižničnog fonda istraživane knjižnice i usluga temeljenih na njima.

\section{LITERATURA}

Cassell, Kay Ann. Interviews with collection development managers. // Collection Building 34, 4(2015), 134-135.

Cej, Višnja; Tea Grašić-Kvesić; Tomislav Silić. Audiovizualna, mutimedijalna i elektronička građa: istraživanje učestalosti korištenja. // Vjesnik bibliotekara Hrvatske 56, 4(2013), 145-168.

31 Vrana, Radovan; Jasna Kovačević. Položaj. Nav. dj. 
Gessesse, Kebede. Collection development and management in the twenty-first century with special reference to academic libraries: an overview. // Library Management 21, 7(2000), 365-372.

Johnson, Peggy. Fundamentals of collection development and management. ALA, 2014.

Lechpammer, Stela. Besplatno čitanje američkog tiska na tabletima u čitaonici. [citirano: 2016-10-30]. Dostupno na http://www.vecernji.hr/zg-zivot/i-doma-ce-se-moci-citati-strana-online-izdanja-1124481.

Mangrum, Suzanne; Mary Ellen Pozzebon. Use of collection development policies in electronic resource management. // Collection Building 31, 3(2012), 108-114.

Mickelsen, Anna. Practice makes perfect. // Library Journal 141, 14(2016), 34-36.

Nebesny, Tatjana; Mira Švob. Izgradnja knjižne zbirke u narodnim knjižnicama. // Slobodan pristup informacijama u službi kulturnog razvitka: zbornik radova. Zagreb: Hrvatsko knjižničarsko društvo, 2002. Str. 56-75.

Novak, Helena. Narodne knjižnice i recesija - ili depresija? // Vjesnik bibliotekara Hrvatske 54, 4(2011), 225-252.

Peet, Lisa. Format follows function. // Library Journal 140, 14(2015), 34-37.

Pejić, Ilija. Narodne knjižnice: potpora formalnom i neformalnom obrazovanju - visoko obrazovanje. // Radovi Zavoda za znanstvenoistraživački i umjetnički rad u Bjelovaru 3(2009), 97-112.

Rossmann, Doralyn. An assessment of the relationships between resource development decisions, library collection usage, and user perceptions. // The Serials Librarian 65, 2(2013), 202-212.

Stoller, Michael. Building library collections: it's still about the user. // Collection Building 24, 1(2005), 4-8.

Soules, Aline. Collections, selection, access. // New Library World 115, 5-6(2014), 263-271.

Tuškan Mihočić, Gorana. Mjerenje uspješnosti poslovanja u narodnoj knjižnici. // Vjesnik bibliotekara Hrvatske 54, 4(2011), 211-224

Upisi i posudba. [citirano: 2016-10-23] Dostupno na http://www.kgz.hr/hr/informacije/ upisi-i-posudba-196/196.

Vrana, Radovan; Jasna Kovačević. Percepcija korisnika o knjižnici i knjižničnim uslugama kao temelj marketinške strategije knjižnice. // Vjesnik bibliotekara Hrvatske 56, 3(2013), 23-46.

Vrana, Radovan; Jasna Kovačević. Pogled na knjižnične usluge iz perspektive korisnika. // Vjesnik bibliotekara Hrvatske 58, 1-2(2015), 135-160.

Vrana, Radovan; Jasna Kovačević. Položaj knjižnice u umreženom društvu. // Vjesnik bibliotekara Hrvatske 53, 3-4(2010), 25-41. 


\section{Prilozi}

\section{Prilog 1. Anketni upitnik}

\section{ISTRAŽIVANJE KORISNIKA - SUDJELUJTE!}

Poštovane korisnice, poštovani korisnici, pred Vama se nalazi anketni upitnik o zadovoljstvu fondom knjižnice u kojoj se nalazite. Molimo Vas da odvojite nekoliko minuta i sudjelujete $\mathrm{u}$ istraživanju.

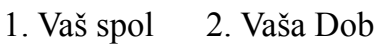

a) $\mathrm{M}$

b) $\check{Z}$

3. Vaša stručna sprema i stupanj obrazovanja:

4. Koliko ČESTO DOLAZITE U KNJIŽNICU (zaokružite slovo ispred odgovora)?
a) Više puta tjedno
b) Jednom tjedno
c) Jednom u dva tjedna
d) Jednom mjesečno
e) Jednom u tri mjeseca
f) Jednom u šest mjeseci
g) Jednom godišnje
h) Rjeđe od jednom godišnje

\section{Prema Vašoj procjeni, KOLIKO VREMENA PROVODITE U KNJIŽNICI}

ČITAJUĆI GRAĐU (novine, časopise, knjige)?
a) Do pola sata
b) Do jednog sata
c) Do dva sata
d) Do tri sata
e) Dulje od tri sata

6. KOLIKO KNJIGA (U PROSJEKU) POSUĐUJETE prilikom jednog posjeta knjižnici? 
7. RAZLOG VAŠEG DOLASKA U KNJIŽNICU (moguće je zaokružiti VIŠE odgovora):

a) Aktivnost povezana s vlastitim obrazovanjem

b) Istraživanje (općenito)

c) Hobi

d) Posao

e) Pronalazak praktičnih informacija

f) Zabava

g) Učenje

h) Kulturni događaji

i) Nešto drugo, navedite što:

8. KOJU VRSTU PUBLIKACIJA (GRAĐE) U KNJIŽNICI OPĆENITO ŽELITE IMATI NA RASPOLAGANJU (moguće je označiti VIŠE odgovora):

a) Knjige - književnost na hrvatskom jeziku

b) Knjige - književnost na stranim jezicima

c) Knjige - publicistiku na hrvatskom jeziku

d) Knjige - publicistiku na stranim jezicima

e) Enciklopedije

f) Znanstvene informacije dostupne u knjižnici putem interneta

g) Znanstvene informacije dostupne u papirnatom obliku

h) Slikovnice

i) Časopise

j) Novine

k) Udžbenike

1) Informacije iz lokalne zajednice

m) Službene (državne) informacije

n) Poslovne informacije

o) Novine na stranim jezicima

p) Knjige na stranim jezicima

q) Časopise na hrvatskom jeziku

r) Časopise na stranim jezicima 
9. Koji su RAZLOZI ZBOG KOJIH ČITATE KNJIGE dostupne u knjižnici? (moguće je zaokružiti VIŠE odgovora)

a) Vlastito zadovoljstvo

b) Posao

c) Obrazovanje (škola, fakultet)

d) Istraživanje

e) Osobni razvoj

f) Hobi

g) Zabava

h) Neki drugi razlog, navedite koji:

10. Koji su RAZLOZI ZBOG KOJIH ČITATE ČASOPISE dostupne u knjižnici? (moguće je zaokružiti VIŠE odgovora)

a) Vlastito zadovoljstvo

b) Posao

c) Obrazovanje (škola, fakultet)

d) Istraživanje

e) Osobni razvoj

f) Hobi

g) Zabava

h) Neki drugi razlog, navedite koji:

11. Na skali vrijednosti od 1 do 5 OCIJENITE VAŠE ZADOVOLJSTVO DOSTUPNOŠĆU sljedećih vrsta građe (1 = najniža ocjena, 5 = najviša ocjena) (ZAOKRUŽITE JEDAN BROJ U SVAKOM REDU):

Knjige (bez obzi- 1----2----3----4----5

ra na jezik i žanr)

Časopisi

$$
1----2----3----4----5
$$

Novine

1----2----3----4----5

Digitalna građa

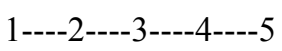

(e-knjige)

Udžbenici, priručnici

Enciklopedije, 1----2-----3----4----5

leksikoni

Rječnici

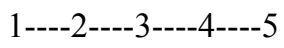


12. Što biste u budućnosti VIŠE VOLJELI KORISTITI u knjižnici u kojoj se trenutno nalazite?

a) Tiskanu (papirnatu) građu

b) Digitalnu građu

13. Označite svoje stavove uz sljedeće tvrdnje:

\begin{tabular}{|l|l|l|l|l|l|l|l|}
\hline 1 & \multicolumn{1}{|c|}{2} & \multicolumn{1}{|c|}{3} & \multicolumn{3}{|c|}{5} \\
\hline $\begin{array}{l}\text { U potpunosti } \\
\text { se ne slažem }\end{array}$ & $\begin{array}{l}\text { Uglavnom } \\
\text { se ne slažem }\end{array}$ & $\begin{array}{l}\text { Niti se slažem } \\
\text { niti se ne slažem }\end{array}$ & $\begin{array}{l}\text { Uglavnom } \\
\text { se slažem }\end{array}$ & \multicolumn{3}{|c|}{$\begin{array}{l}\text { Slažem se u pot- } \\
\text { punosti }\end{array}$} \\
\hline & & 1 & 2 & 3 & 4 & 5 \\
\hline Građa je adekvatna mojim informacijskim potrebama & & & & & \\
\hline Građa je adekvatna mojim kulturnim potrebama & & & & & \\
\hline Građa je adekvatna mojim obrazovnim potrebama & & & & & \\
\hline Građa je recentna (novijeg datuma) & & & & \\
\hline Građu je u knjižnici lako pronaći & & & & & \\
\hline $\begin{array}{l}\text { Obično uspijevam pronaći građu koju tražim } \\
\text { primjeraka građe } \\
\text { o građi, ali ju ne mogu pronaći u knjižnici }\end{array}$ & & & & & \\
\hline Ne uspijevam pronaći građu jer ju knjižnica nema & & & & & \\
\hline Ne uspijevam pronaći građu jer su svi primjerci posuđeni & & & & \\
\hline $\begin{array}{l}\text { Ne uspijevam pronaći građu jer knjižnica nema dovoljan broj } \\
\text { Ne nudi podatke }\end{array}$ & & & & & \\
\hline
\end{tabular}

HVALA NA SUDJELOVANJU! 